\title{
NIH tightens up monitoring of gene-therapy mishaps
}

Washington

The US National Institutes of Health (NIH) is telephoning every investigator who has registered a clinical trial in gene therapy, in an expanded effort to track down unreported adverse events. Its results will be made available on the Internet by the end of the year, in a bid to respond to public concerns.

The move represents a shift of policy for the NIH. The Recombinant DNA Advisory Group first proposed a database of adverse effects of gene therapy in 1996. But this failed to materialize after Harold Varmus, then NIH director, removed much of the group's regulatory authority for gene therapy.

The telephone campaign reflects concern over the extent to which investigators have been ignoring the rules on reporting. Gene therapy researchers must report all adverse events - ranging from fever to death - to both the US Food and Drug Administration (FDA) and the NIH.

But the requirement has frequently been ignored. While most have reported adverse events to the FDA, which keeps such information confidential, few have submitted them to the NIH, which makes it public.

The issue was highlighted by the death of 18-year-old Jesse Gelsinger at the University of Pennsylvania last September (see Nature 401, 517; 1999). The NIH subsequently sent requests for information to all institutions conducting research in adenoviral vectors the type of vector received by Gelsinger, and used in about 25 per cent of active gene therapy trials.

A month later, the agency wrote to all institutions that have participated in any gene therapy clinical trials, regardless of the vector used. Hundreds of unreported events came to light, including several deaths not directly attributable to the experimental treatment.

Lana Skirboll, NIH associate director of science policy, says that the telephone calls are revealing still more adverse events, almost six months after the NIH sent its first letters asking for them. She adds that she is surprised by the level of non-compliance. Many investigators have said they thought they only had to notify the FDA.

Officials from both NIH and FDA were grilled at a Senate hearing last month where William Frist (Republican, Tennessee) said that the two agencies had not communicated enough about gene therapy's adverse events in the past (see Nature 403, 583; 2000).

The new commitment to reporting and disseminating information about adverse effects appears to be a response to congressional and public pressure, after high-profile stories appeared in the popular press. But some researchers question whether the reaction is appropriate, since the vast majority of these deaths are probably due to the patients' underlying disease.

Dusty Miller, for example, of the Fred Hutchinson Cancer Research Center in Seattle, applauds the information gathering. But, he asks, "How many of these adverse events are truly related to gene therapy?"

Inder Verma, professor of genetics at the Salk Institute in La Jolla, California, says that the public's response is a predictable result of releasing information that was once kept private. But he acknowledges that the abundance of information - as well as the heightened scrutiny caused by Gelsinger's death has its disadvantages.

Newspaper reports that 20 patients in a cancer gene therapy trial were exposed to



Verma: database needs right design. HIV, for example, turned out to be inaccurate. "The more reporting that is done, the better," says Verma, president-elect of the American Society of Gene Therapy. But he remains concerned about the form in which the NIH makes the data available.

"Someone has to put the data together in a meaningful manner," says Verma. Many people feel that a properly designed database would allow researchers and patients to compare the effects of different vectors and doses in the same organ, helping them to weigh up the risks against the benefits.

Skirboll pledges that the NIH will have such a database up by the end of the year. But it remains unclear whether it will contain only adverse events directly related to gene therapy, or all adverse events that take place during or following the trial.

The field is in disagreement over this point, says Miller. Pharmaceutical and biotech representatives have repeatedly pushed for databases that only contain the adverse events directly attributable to gene therapy. Miller prefers a database containing all adverse events, but acknowledges that would be "an overwhelming amount of data".

Without proper organization, researchers could be deluged with information that they may be unable to turn into knowledge, says Verma. He adds that a properly organized, clearly accessible database could also help win back the public trust needed to get new clinical trials launched.

Paul Smaglik

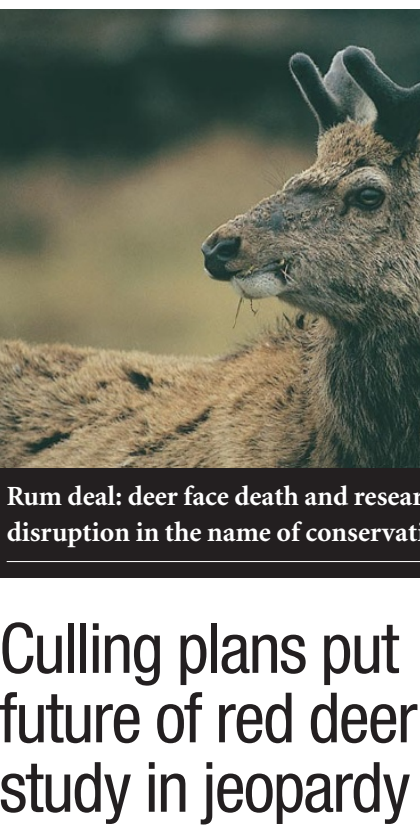

London

A world-renowned study of red-deer population dynamics on a Scottish island is being threatened by a culling proposal.

Red deer on Rum, off Scotland's west coast, have been studied by biologists for three decades in what is considered to be one of the world's most significant longterm studies of mammal populations.

But the island's owner, Scottish Natural Heritage (SNH), which is responsible for safeguarding and enhancing the "natural, genetic and scenic diversity" of Scotland, is considering reducing deer numbers from 1,500 to around $300-400$.

"Our long-term aim for managing Rum is restoration and conservation," says Michael Usher, SNH's chief scientist. "That does not sit happily with a very large deer population."

At present, SNH culls only 200 head of deer a year on the island outside the study area. It now wants to restore the natural balance of wildlife, open-ground vegetation, native woodland and scrub. To help achieve this, woodland lost through overgrazing would be recreated.

Additional pressure results from the fact that Rum has been proposed as a special conservation area, under a directive on natural habitats issued by the European Commission. Under this directive, $\mathrm{SNH}$ is obliged to bring the features of interest into favourable conservation condition. "At the moment we would argue they are not, because they are overgrazed," says Usher.

The deer that most interest the population biologists live within a small, currently unculled region of the island known as the 'north block'. This part is not under immediate threat — new plans for culling and tree planting will begin in 
the south, with the northern population remaining safe for at least another five years.

Scientists are concerned that the plans could herald the end of an internationally valuable long-term population study, and hope that $\mathrm{SNH}$ will consider leaving the northern-block population alone.

"The long-term red-deer study has profoundly influenced our understanding of important conceptual issues in evolutionary biology - for example, sexual selection and sex allocation and population biology, including factors such as density dependence and the maintenance of genetic variation," says Andrew Cockburn, a behavioural ecologist at the Australian National University in Canberra, who is familiar with the studies.

"The research also has had great consequences for our understanding of the management of ungulate populations. Perhaps most important, the study has clearly not run its course, as fascinating recent results on sex ratios attest. It would be very disappointing to see the work come to an end."

Josephine Pemberton, a population biologist at the University of Edinburgh is one of the authors of a recent paper on sex ratios in Rum red deer (see Nature $399,459 ; 1999)$. She says the deer, which are individually monitored, "should be seen as a national and international resource for research and education which has its own intrinsic value".

Usher acknowledges the researchers' concerns. But he argues that they should now be addressing the substantial opportunities for researching how a deer population at normal density would change in a more diverse landscape.

Another scientist suggests that Rum could be treated as a demonstration case for other areas of Scotland where similar replanting is occurring next to high-density deer populations. "You would have to accept high-density populations of deer in areas adjacent to where conservationists want to plant," says Steve Albon, from the Institute of Terrestrial Ecology in Banchory, Scotland.

Although SNH says it is committed to the concept of Rum as an outdoor laboratory, it wants to limit future research. A spokesperson said "we do have a difficulty with current research work, which is conflicting with the management of the reserve". SNH's vision includes increasing visitor numbers to the island and, in the long term, allowing more people to live there.

\section{Young, worldly and unhelpful all miss out on data sharing}

\section{Washington}

Researchers who refuse to share data may provoke others to withhold results from them, according to a study by health-policy analysts at Harvard Medical School.

The study found that young researchers, those who publish a lot, and investigators seeking patents are most likely to be denied access to biomedical data and reagents. It also found that researchers who withhold data gain a reputation for this and have more difficulty in obtaining data from others.

The study, whose results are published in the February issue of Research Policy, was conducted by a research team led by sociologist Eric Campbell at Harvard Medical School's Institute of Health Policy.

The team surveyed 2,366 randomly selected scientists - both clinical and nonclinical — at 117 US medical schools. Overall, 12.5 per cent said they had been denied access to other academic investigators' data, excluding article reprints, during the past three years. This corresponds with previous findings by the team and other groups.

But, by examining the 'victims' of data withholding, the team identified those experiencing the most difficulty. For junior staff members, the team found that 13.5 per cent were denied access, compared with 5.1 per cent of senior researchers.

The relationship between data withholding and researchers' publishing records during the preceding three years was striking: 7.7 per cent of those who had published 1-5 articles had had data withheld from them, but this rose to 28.9 per cent for researchers who had published more than 20

Among those who had applied for a patent, 30 per cent had been refused access to data, compared with 9.4 per cent of those

Researchers denied access to data over the past three years

Researcher Percentage of requests denied

\begin{tabular}{ll} 
Has MD & 9.2 \\
\hdashline & 1
\end{tabular}

No MD 17.7

Publishing record:

$1-5$ articles $\quad 7.7$

$>20$ articles $\quad 28.9$

Applied for patent?

Yes $\quad 30$

No 9.4

Member of federal review board/study panel?

Yes $\quad 20.2$

No 1.6

who had not applied for a patent. Scientists who reported refusing to share data were more than twice as likely to be the victims of data withholding as those who had not.

"Selectively withholding research results from the most productive and commercially active researchers could slow the progress towards understanding the causes and cures of human disease," warns Campbell.

The National Institutes of Health issued guidelines last year encouraging the sharing of materials and data, but some scientists say these need tightening. Campbell and his colleagues make several recommendations to institutions regarding data sharing. For example, they suggest that senior staff should be encouraged to help junior scientists gain access to results and materials from other researchers and that professional societies and funding agencies should encourage data sharing.

"We welcome the study," said Jonathan Knight, associate secretary of the American Association of University Professors. "The study shows some concrete dimensions to the problem."

Rex Dalton

\section{US eases Israelis' lab access}

\section{Jerusalem}

Israeli scientists will have an easier time visiting and working with laboratories run by the US Department of Energy under an agreement signed last week.

Under the terms of the agreement, signed by US Secretary of Energy Bill Richardson and Israel's Minister of National Infrastructure, Eli Suissa, Israeli scientists will no longer have to undergo thorough and lengthy security clearances before being allowed to visit the laboratories.

These clearances were imposed on Israeli scientists in the wake of the conviction of
Jonathan Pollard, an American who spied for Israel, in 1986. They were tightened up in 1998 following of the arrest of Wen Ho Lee, a Los Alamos scientist who is suspected of spying for China.

At their meeting last week, Richardson and Israeli officials also discussed cooperation on technical means of monitoring the Nuclear Non-proliferation Treaty.

Israel has declined to sign the treaty and has maintained a deliberate silence about its nuclear weapons programme. However, the country is widely believed to have built up a nuclear arsenal.
Haim Watzman 